\title{
A Two-Phase Method to Assess the Sustainability of Water Companies
}

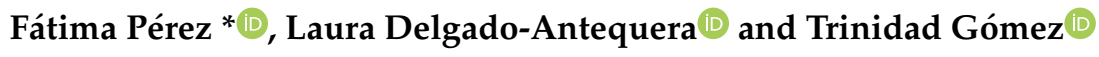 \\ Departamento de Economía Aplicada, Universidad de Málaga, 29016 Málaga, Spain \\ * Correspondence: f_perez@uma.es
}

Received: 29 May 2019; Accepted: 5 July 2019; Published: 9 July 2019

\begin{abstract}
Composite indicators are becoming more relevant for evaluating the performance of water companies from a holistic perspective. Some of them are related with economic aspects, and others focus on social and environmental features. Consequently, a multidimensional evaluation is necessary for handling the great amount of information provided by multiple single indicators of a different nature. This paper presents a two-phase approach to evaluate the sustainability of water companies. First, a partial composite indicator for each dimension (social, environmental, economic) is obtained using multi-criteria decision making (MCDM). Then, a global indicator is obtained, in terms of the values reached in the previous stage for every partial indicator, by means an optimization problem rooted in data envelopment analysis (DEA). Our proposal offers the possibility of analyzing the performance of each water company under each dimension that characterizes the concept of sustainability, as well as a joint assessment including all the dimensions, facilitating the decision-making process. We apply it to evaluate the sustainability of 163 Portuguese water companies. The results show the strengths and weaknesses of each unit and serve as a guideline to decision-makers on the aspects for improving the performance of water utilities.
\end{abstract}

Keywords: composite indicator; sustainability; water utilities management; data envelopment analysis; multi-criteria decision making (MCDM)

\section{Introduction}

The evolution of water management is a key issue for the human development. An effective performance of such service is a challenge for the community. Designing a good management system requires considering different factors. In countries such as England and Wales, Portugal, Chile, or the Netherlands, the water industry exists as a monopoly, so that companies and administrations invest their efforts on comparing the different processes within the industry. In general, benchmarking is widely considered a good strategy to control and supervise the performance of this service. Ref. [1] provide a rigorous evaluation of the growing number of benchmarking studies dealing with performance scores based on production or cost estimates. At the same time, the literature reveals frequent use of performance indicators (PIs) when dealing with benchmarking, because of the multiple benefits it brings to the administrations, for instance, to contrast the regulatory conditions, compare, and/or evaluate the quality of the service and establish fair tariff policies. So, in order to control these values, water utilities-following industry regulations- provide systematic reports on different PIs to the government or administrators. The information delivered within this data includes management, environmental, financial and, more recently, social aspects related to water operations. However, different reasons make this set of indicators difficult to interpret because they do not offer a holistic view, as they do not reflect a measure of general performance.

To overcome this difficulty, a common approach is to aggregate the PIs into a unique indicator, named a composite indicator $(\mathrm{CI})$. Although the literature offers a wide range of techniques to create a 
CI, most of them use methodologies from multi-criteria decision analysis (MCDA). They have been used to develop CIs applied to diverse sectors of services, activities, or processes [2-4]. In particular, methodologies based on goal programming (GP) are of great interest for the construction of CIs and they have been successfully applied to diverse fields as tourism [5,6], manufacturing [7], human sustainable development [8-10], or environmental sustainability [11,12]. The main advantages of using GP to develop CIs are: it is not necessary to normalize the initial set of PIs; the CI uses the complete information included in the initial set of PIs; and it does not require a large number of units in comparison with the number of initial indicators.

Usually, another technique used to create CIs is data envelopment analysis (DEA) [13]. DEA is a linear programming tool for evaluating the performance of a set of peer entities that use one or more inputs to produce one or more outputs. As pointed out by [14], the main advantages of using DEA to construct CIs are: it provides a measure of performance based on real data; DEA models do not require the normalization of the initial data; and DEA respects the individual characteristics of the units and their own particular value systems. Techniques based on DEA have been developed to create CIs in $[6,15-17]$.

Since the 1990s, governments of many countries and organizations have emphasized the importance of the concept of sustainability [18]. There is no consensus on the definition of this concept, although it is widely agreed that it must incorporate social, environmental, and economic factors which are interconnected $([19,20])$. The water industry has not ignored this trend and, currently, it has extensively recognized its important role in establishing and operating sustainable water supplies and wastewater treatment systems [2,21]. There is clearly a need for a paradigm shift in the water companies, considering social and environmental aspects in the decision making process, not just economic issues [22,23]. In the framework of evaluating the sustainability of water companies, most of the literature focuses on evaluating the sustainability of physical and engineering aspects [24-26], from an environmental perspective [27] or economic sustainability [28,29]. However, there is a lack interest on assessing the sustainability of water companies themselves. In particular, only a few papers apply different techniques from MCDA to assess the sustainability of water companies from a multidimensional perspective. For instance, Ref. [30] construct an index by aggregating the PIs as a linear combination of their normalized values. Also, the MACBETH (Measuring Attractiveness by a Categorical Based Evaluation Technique [31]) method is used to evaluate the sustainability of water supply systems [24]. Another example, Ref. [19], applies the ELECTRE TRI-Nc (Elimination and Choice Expressing Reality [32]) method as a tool to integrate the dimensions of a quality of service index. Additionally, Ref. [12] combines the PIs using an index based on distance-principal components and another based on GP.

In view of the above, in this work, a method to assess the sustainability of the water companies is conducted, using the traditional approach of sustainability, which considers three dimensions into this concept: social, environmental, and economic. Then, a two-phase method combining GP and DEA is proposed, in order to take advantage of both methodologies. A similar two-phase method is proposed in [6] to evaluate the sustainability of Cuban nature-based tourism destinations. Nevertheless, in that work, the distance-principal component (DPC) composite indicator developed by [33] is used to sum up the initial PIs into the dimensions established (social, economic and patrimonial (Although it is usual to use "environmental dimension", in [6] it is replaced by "patrimonial dimension".) instead of GP. Choosing a technique based on GP comes from their good properties, as previously mentioned.

Then, in the first phase, a technique based on GP [5] is used to obtain the dimensional or partial CIs. In the field of water treatments, there is a lack of consensus on the appropriate criteria to select, in order to determine which PIs are involved in evaluating the status of water sustainability. Then, to overcome this difficulty, as suggested by [34], our proposal groups the initial indicators into the dimensions that characterize the concept of sustainability: social, economic, and environmental dimensions. In this way, when the first phase is applied, three-dimensional composite indicators (social, environmental, 
and economic) are obtained for each water company. This allows for independently analyzing the performance of each water company among these three dimensions.

Later, in the second phase, the dimensional indicators have to be aggregated in order to design a global composite indicator for evaluating the water companies' sustainability. At this point, a controversial question is the assignment of weights to each dimensional indicator. On the one hand, under some circumstances, it is not easy to obtain information from specialists to determine these weights. On the other hand, the assignation of the same weighting values for all the water companies could be complicated, as each of them might have their own particularities in terms of preferences. To overcome these issues, we have chosen, in the second phase, a DEA-based model known as "Benefit-of-the-Doubts" [32]. To do this, the values obtained in the previous stage are used as outputs of this "Benefit-of-the-Doubt" approach.

This two-phase approach offers the possibility of considering the strengths and weaknesses of each water company, as well as providing the decision-makers with useful information.

The hypothesis behind this study is that the water companies should manage their activity in a way as balanced as possible, from social, environmental, and economic point of view. In this sense, the approach proposed in this work allows evaluating and comparing the performance of water companies for each sustainability dimension and, later, identifying if such dimensions have or not a similar influence on the global score. This aspect is an advantage of the proposed approach in comparison to other procedures. In the first phase, an indicator is obtained for each sustainability dimension, and in the second phase the different sustainability dimension indicators are aggregated to build a global indicator. In this aggregation, the weights of the different dimensional indicators are endogenously determined using a DEA-based model, allowing each water company to be assessed in the most favorable way for it. This is another advantage of our proposal, since it does not demand excessive information for obtaining the global indicator.

This study, therefore, presents a pioneering and novel approach to assess the sustainability of water companies. To the best of our knowledge, there is neither any theoretical development nor empirical application that uses composite indicators to assess and/or compare the sustainability of water companies, for each dimension of sustainability and for all the dimensions, simultaneously. Thus, the dimensional composite indicators, in the first phase, allow evaluating the strengths and weaknesses of each water company in a particular dimension. The global indicator, in the second phase, provides a holistic performance perspective, and allows ranking the water companies. However, it provides information about the contribution of the different dimensions to the sustainability overall score.

In the next section, the methodology proposed is detailed. Section 3 introduces the case study, embracing 163 Portuguese water companies as well as the results obtained. Finally, the main conclusions derived from the research are presented in the last section.

\section{A Two-Phase Evaluation Method}

In this section, the methodology developed to construct the sustainability composite indicator is described, in order to evaluate the performance of water companies.

As previously mentioned, a two-phase procedure is proposed. In the first phase, following the proposal by [5], the composite indicator (sub-indicator) for each dimension of sustainability is calculated: SSUI $^{d}$ (Partial Sustainability Indicator of dimension $d$ ). In the second phase, these partial indicators form the basis from which the overall composite indicator is obtained, applying a variant of DEA named the "Benefit-of-the-Doubt" approach. Figure 1 shows the general scheme of the proposed approach. 


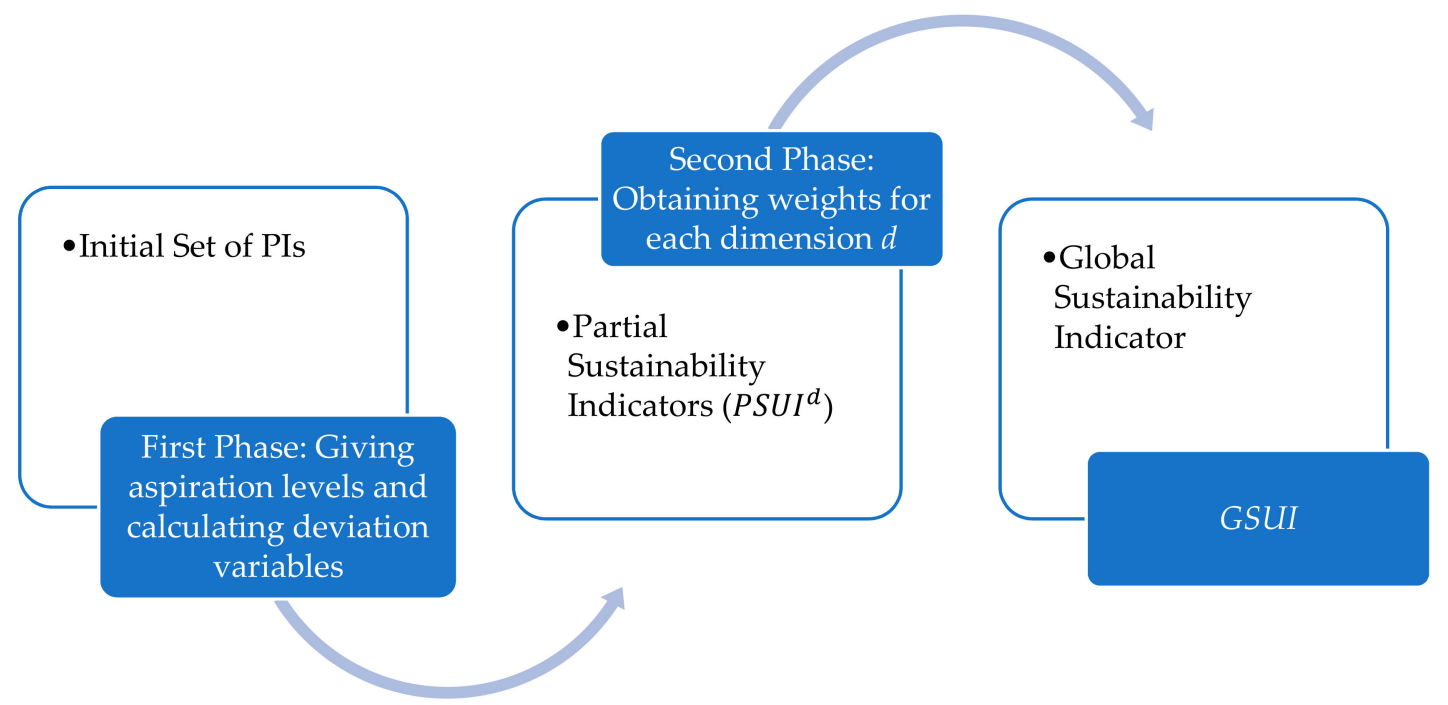

Figure 1. General scheme of the proposed approach.

Then, to calculate $P S U I^{d}, d=1,2, \ldots, D$, it is necessary to distinguish between positive PIs (a larger value involves an improvement in the sustainability) and negative PIs (a larger value involves a decline in the sustainability). Let us suppose that the initial set of PIs is divided into $D$ dimensions and there are $M$ units to evaluate. For each $d \in D$, let us denote by $J^{d}$ and $K^{d}$ the number of positive and negative PIs, respectively, assigned to dimension $d$, and $I_{i, j^{d}}^{+}$and $I_{i, k^{d}}^{-}$the value of the $i$-th unit with respect to the $j^{d}$-th positive and $k^{d}$-th negative PI which belong to the dimension $d\left(i=1,2, \ldots M ; j^{d}=\right.$ $\left.1,2, \ldots J^{d} ; k^{d}=1,2, \ldots K^{d} ; d=1,2, \ldots D\right)$.

Additionally, the performance of a unit is evaluated, regarding PIs, using the concept of "aspiration level", that is, the achievement level desired for the corresponding PI. Thus, it is possible to obtain a set of goals in line with the basic ideas underlying in GP approach [35]. Accordingly, let us assume that, for each positive PI, it is possible to give an aspiration level (denoted by $u_{j d}^{+}$). It corresponds to the minimum value from which it is considered that a unit shows a suitable performance, regarding the aspect of sustainability evaluated by the PI. Thus, for the $i$-th unit, the goal corresponding to the $j^{d}$-th positive PI can be defined as follows:

$$
I_{i j^{d}}^{+}+n_{i j^{d}}^{+}-p_{i j^{d}}^{+}=u_{j^{d}}^{+} \text {with } n_{i j^{d^{\prime}}}^{+} p_{i j^{d}}^{+} \geq 0, n_{i j^{d}}^{+} \cdot p_{i j^{d}}^{+}=0
$$

where $n_{i j^{d}}^{+}, p_{i j^{d}}^{+}$represent the negative and positive deviation variables, respectively. Thus, if the goal is satisfied $\left(I_{i j^{d}}^{+}>u_{j^{d}}^{+}\right)$, the negative deviation variable would be zero, and the positive deviation variable would measure the over-achievement of the goal (strength). Otherwise, if the goal is not satisfied $\left(I_{i d^{d}}^{+}<u_{j d}^{+}\right)$, the positive deviation variable would be zero and the negative deviation variable would quantify the under-achievement of the goal (weakness). It should be noted that, at least, one of the two deviation variables has to be zero. Consequently, for positive PIs, the negative deviation variables will be considered unwanted variables because a better-positioned company will achieve the aspiration level or a higher value.

In a similar way, for each negative PI, we have the following goal:

$$
I_{i k^{d}}^{-}+n_{i k^{d}}^{-}-p_{i k^{d}}^{-}=u_{k^{d}}^{-} \text {with } n_{i k^{d}}^{-}, p_{i k^{d}}^{-} \geq 0, n_{i k^{d}}^{-} \cdot p_{i k^{d}}^{-}=0
$$

Again, $n_{i k^{d}}^{-}, p_{i k^{d}}^{-}$represent the negative and positive deviation variables, respectively. However, now, if the goal is satisfied $\left(I_{i k^{d}}^{-}<u_{k^{d}}^{-}\right)$, the positive deviation variable would be zero and the negative deviation variable would quantify the under-achievement of the goal (strength). Otherwise, if the goal 
is not satisfied $\left(I_{i k^{d}}^{-}>u_{k^{d}}^{-}\right)$, the negative deviation variable would be zero, and the positive deviation variable would quantify the over-achievement of the goal (weakness). Consequently, for negative PIs, the positive deviation variables will be considered unwanted variables because a better-positioned company will achieve the aspiration level or a lower value.

From all the above, at each dimension $d$, the strengths of each unit can be calculated by aggregating positive deviation variables, in case of positive PIs, and negative deviation variables, for the negative PIs. These variables are normalized by their corresponding aspiration levels to avoid the inadequate effects due to the use of different measurement scales of the initial set of PIs. Similarly, the weaknesses of each water company can be obtained as the sum of the normalized unwanted deviation variables (negative deviation for positive PIs and positive deviation for negative PIs divided by its corresponding aspiration level). Finally, the partial indicator for the $i$-th $(i=1,2, \ldots M)$ unit, in the dimension $d(d \in D)$ is determined by the difference between the strengths and weaknesses of this unit as follows:

$$
\widetilde{P S U I}_{i}^{d}=\left(\sum_{j^{d}=1}^{J^{d}} \frac{p_{i j^{d}}^{+}}{u_{j^{d}}^{+}}+\sum_{k^{d}=1}^{K^{d}} \frac{n_{i k^{d}}^{-}}{u_{k^{d}}^{-}}\right)-\left(\sum_{j^{d}=1}^{J^{d}} \frac{n_{i j^{d}}^{+}}{u_{j^{d}}^{+}}+\sum_{k^{d}=1}^{K^{d}} \frac{p_{i k^{d}}^{-}}{u_{k^{d}}^{-}}\right)
$$

Additionally, two fictitious units are introduced in the sample, representing the best and worst situation within the data base. For each positive indicator in dimension $d, j^{d}$, and negative PI, $k^{d}$, the value of the "best" unit $(b)$ will be:

$$
I_{b j^{d}}^{+}=\operatorname{Max} i \in M\left\{I_{i j^{d}}^{*}\right\}, I_{b k^{d}}^{-}=\operatorname{Min}_{i \in M}\left\{I_{i k^{d}}^{-}\right\}
$$

and the value of the worst unit $(w)$ :

$$
I_{w j^{d}}^{+}=\operatorname{Min}_{i \in M}\left\{I_{i j^{d}}^{*}\right\}, I_{w k^{d}}^{-}=\operatorname{Max} i \in M\left\{I_{i k^{d}}^{-}\right\}
$$

For these fictitious units, their corresponding partial sustainability indicators are calculated. Finally, we can obtain the difference between $\widetilde{\operatorname{PSUI}}_{i}^{d}$ with respect to the value reached by the worst unit and normalize this value by the difference between the partial sustainability indicator for the best and the worst unit, that is:

$$
\operatorname{PSUI}_{i}^{d}=\frac{\widetilde{P S U I}_{i}^{d}-\widetilde{\operatorname{PSUI}}_{w}^{d}}{\widetilde{P S U I}_{b}^{d}-\widetilde{\operatorname{PSUI}}_{w}^{d}}, \quad i=1,2, \ldots, M ; d \in D
$$

The advantage of using PSUI ${ }_{i}^{d}$ instead $\widetilde{P S U I}_{i}^{d}$ is that it offers a relative value between 0 and 1. In fact, it represents how far a unit is from the worst situation regarding the distance between the best and the worst situation. Additionally, this normalization does not distort the previously obtained results, but allows a more homogeneous and simple analysis of the dimensional results obtained.

Once the partial sustainability indicators for each dimension are obtained, the second phase consists of calculating the global sustainability indicator (GSUI). To do so, the "Benefit-of the-Doubt" approach [36], which is rooted DEA, is applied.

Now, for each unit $a, \operatorname{GSUI}_{a}(a=1,2, \ldots M)$ represents the weighted average of the partial indicators $\operatorname{PSUI}_{a}^{d}(d \in D)$, which is obtained by solving the following optimization problem:

$$
\mathrm{GSUI}_{a}=\operatorname{Max} \sum_{d \in D} w_{a}^{d} P S U I_{a}^{d}
$$


Subject to:

$$
\begin{gathered}
\sum_{d \in D} w_{i}^{d} \operatorname{PSUII}_{i}^{d} \leq 1 ; i=1,2, \ldots, a \ldots, \ldots M \\
L^{d} \leq \frac{w_{i}^{d} P \operatorname{PSII} I_{i}^{d}}{\sum_{d \in D} w_{i}^{d} \operatorname{PSUI} I_{i}^{d}} \leq U^{d} ; i=1,2, \ldots, a \ldots, \ldots M ; d \in D \\
w_{i}^{d^{d}} \geq 0 i=1,2, \ldots, a \ldots, \ldots M ; d \in D
\end{gathered}
$$

where $U^{d}$ and $L^{d}$ are the upper and lower bounds allowed for the relative contribution of PSUI ${ }^{d}$ to the global indicator. The aim of Equation (7) is to obtain the weights (assigned to the partial indicators) that maximize the global score $\left(G S U I_{a}\right)$ for every unit $a$. Therefore, this model provides a relative objective performance value for each unit without requiring prior knowledge of the weights for the partial indicators [37]. These weights are endogenously determined solving Equation (7) and, by construction, GSUI $_{a}$ takes value between 0 (the worst situation) and 1 (the best situation).

In essence, Equation (7) is an output multiplier DEA model with multiple outputs (partial indicators) and a single "dummy input" with value equal to 1 for all the units [38]. In the DEA context, the contribution of each partial indicator to the value of the global indicator $\left(w_{i}^{d} P S U I_{i}^{d}\right)$ is labelled as the "virtual output" of the corresponding dimension.

To avoid extreme situations, some constraints on the weights have been added to Equation (7). All partial indicators should have a relative contribution on the global indicator, that is, all the dimensions should be taken into account in the global score. For this reason, lower and upper bounds $\left(U^{d}\right.$ and $\left.L^{d}\right)$ have been established on the relative contribution of each partial indicator $\left(P S U I^{d}\right)$.

Thus, the proposed approach offers a composite indicator which provides information about the contribution of each sustainability dimension to the global score. It allows to take into account the special characteristics of the units considered since the same importance does not need to be given to each dimension for the different units.

\section{A Real Application}

\subsection{Data Description}

Our aim is to use the concept of sustainability proposed by [20] to evaluate the performance of Portuguese water companies. In Portugal, we find two kinds of water companies: on the one hand, there are companies that provide services in all activities involved in the urban water cycle and, on the other hand, there are companies that focus on the distribution of drinking water and collection of wastewater. In any case, a national authority (ERSAR: Entidade Reguladora dos Serviços the Águas e Resíduos (www.ersar.pt)) regulates all companies. ERSAR states different regulatory functions over all the operators related to waste and water management. The statutes of ERSAR impose significant regulatory functions among the operators in charge of waste and water management in Portugal. Their concern is to respect customer rights and safeguard sustainability, as well as to provide economic visibility of the systems. In particular, this national authority applies the sunshine regulation model [39], which consists of sharing the information derived from a set of specific performance indicators that is provided by the operators. There are several factors that differentiate the Portuguese water companies, such as the management model or the regional location, among others. Portugal offers different management models for their water companies [19]: direct management (municipalities, municipalized services, and associations of municipalities); delegation (municipal-owned company or company established in partnership with the State (municipal or State-owned company), parishes, or user associations), and concession (municipal concessionaire or public-private partnership-municipality or municipalities and other private operators). In general, most of the municipalities receive the service directly from the municipal departments or municipal services with autonomy. This regulatory model has some strengths (the quality of service, the technical regulation and the access to information) but it also has some weaknesses (poor governance and failure to address identified problems). The evolution of the Portuguese water industry has been widely studied. However, some internal problems remain 
(water losses, poor staff productivity,... ), in addition to the fact that the sector is excessively politicized. A more detailed description about this model of regulation and its characteristics can be found in [19].

To show the potential of the methodology proposed in the previous section, we consider an initial set of indicators applied to a set of Portuguese water companies. In the selection of these sustainability metrics, we take into account the availability of statistical data [37], as well as their relevance. The selection of these indicators is analogous to [12], whose data were obtained from the ERSAR list of Portuguese water companies in 2012. Nevertheless, on this occasion, data is updated to 2015 and, besides, the present work really makes use of the classification into three dimensions established in [12], in order to carry out the first phase of our approach. Then, 14 initial indicators are set, divided into three dimensions: social (5), environmental (5), and economic (4). In general, IS denote social indicators, whereas IEN are those related with environmental issues and IEC for the economic indicators.

Table 1 summarizes the main features of each initial PI, as well as the direction of improvement (negative or positive PIs), unit, average and standard deviation (for more details see Appendix A: Table A1). In particular, IS4, IS5, IEN4, and IEN5 are binary indicators, so they get a value of 1 if the water company has the certification, or 0 otherwise.

Table 1. Direction of improvement and statistical information from the initial set of PIs.

\begin{tabular}{ccccc}
\hline Acronym & Direction & Unit & Average & Standard Deviation \\
\hline IS1 & Positive & $\%$ & 86.62 & 8.93 \\
IS2 & Positive & $\%$ & 99.15 & 1.01 \\
IS3 & Positive & Days & 1.46 & 0.9 \\
IS4 & Positive & - & 0.15 & 0.36 \\
IS5 & Positive & - & 0.09 & 0.29 \\
IEN1 & Negative & $\mathrm{m}^{3} / \mathrm{km} /$ day & 127.63 & 104.62 \\
IEN2 & Positive & $\%$ & 0.56 & 2.69 \\
IEN3 & Negative & $\mathrm{kWh}\left(\mathrm{m}^{3} / 100 \mathrm{~m}\right)$ & 0.88 & 0.65 \\
IEN4 & Positive & - & 0.15 & 0.36 \\
IEN5 & Positive & - & 0.31 & 0.47 \\
IEC1 & Negative & $\%$ & 37.11 & 14.94 \\
IEC2 & Negative & Number $/ 10^{3}$ connections & 2.15 & 1.05 \\
IEC3 & Positive & $\%$ & 92.99 & 33.34 \\
IEC4 & Positive & - & 49.16 & 26.31 \\
\hline
\end{tabular}

Regarding water companies, Table 2 provides information related to the localization of them. In this sense, following the classification from Eurostat, the NUTS classification (Nomenclature of Territorial Units for Statistics) is a hierarchical system for dividing up the economic territory of the European Union. In particular, NUTS II are basic regions for the application of regional policies. Then, Portugal (continental) is divided into five regions or NUTS II (North, Centre, Metropolitan Area of Lisbon (MA Lisbon), Alentejo, and Algarve). Most of the water companies are located in the North (48) and Centre (58) regions, a large group is equally located in the Alentejo (30) region, and just a few of them are located in Algarve (12) and MA Lisbon (15) regions.

Table 2. Localization of the water companies and characteristics of the regions.

\begin{tabular}{|c|c|c|c|c|c|c|}
\hline $\begin{array}{l}\text { Region } \\
\text { (NUTS II) }\end{array}$ & $\begin{array}{c}\text { Water } \\
\text { Companies }\end{array}$ & Area $\left(\mathrm{Km}^{2}\right)$ & $\begin{array}{l}\text { Population } \\
\text { (2011) }\end{array}$ & Pop/km² & $\begin{array}{l}\text { Share in National } \\
\text { GDP \% (2017) }\end{array}$ & $\begin{array}{l}\text { GDP per Capita } \\
(€)(2017)\end{array}$ \\
\hline North & 48 & 21,285 & $3,689,682$ & 173.35 & $29.40 \%$ & 16,000 \\
\hline MA Lisbon & 15 & 2802 & $2,821,876$ & 1007.09 & $36.00 \%$ & 24,700 \\
\hline Alentejo & 30 & 27,292 & 757,302 & 27.75 & $6.50 \%$ & 17,800 \\
\hline Algarve & 12 & 4960 & 451,006 & 90.93 & $4.60 \%$ & 20,500 \\
\hline
\end{tabular}


Additionally, general information (obtained from Eurostat) about these NUTS II are shown in Table 2, in order to clarify the main characteristics of the regions in which the water companies are located. Thus, Centre and Alentejo regions are the largest areas, while MA Lisbon region is the smallest. Nevertheless, the last one presents the highest population per $\mathrm{km}^{2}$ (1007.09 population). Finally, MA Lisbon region gets the highest GDP per capita $(24,700 €)$, representing $36.00 \%$ of the total Portugal GDP; while the Centre region gets the lowest GDP per capita $(16,000 €)$, representing the $29.40 \%$ of the total Portugal GDP.

\subsection{Results and Discussion}

Taking into account the case study described above, Figure 2 displays a visual scheme of our methodological approach to evaluate the case of the Portuguese water companies. Let us assume that every initial indicator is already assigned to a dimension. Observe that Phase 1 entails designing partial sustainable indicators $\left(P S U I^{d}\right)$, in order to analyze the situation of water companies for each particular dimension, based on the information provided by the corresponding initial indicators. Afterwards, Phase 2 summarizes the information provided by these PSUI $^{d}$ into a global indicator (GSUI).

\subsubsection{Phase 1: $P S U I_{i}^{d}$ Calculation}

The first phase addresses the calculation of $P S U I_{i}^{d}$. To do this, the aspiration levels for each indicator have to be established. Our proposal follows previous works $[5,12,40,41]$, so that, for positive initial indicators, the aspiration levels were set to the $80 \%$ value of the mean for each initial indicator; whereas in the case of negative initial indicators, the reciprocal percentage of the mean was used.

Results obtained are shown in Figure 3 (Water companies are listed following the ranking obtained for the global indicator in the second phase. The numbers associated with the water companies are provided in Table 5). For each water company, a set of three values is represented in different colors which denote each dimension. Note that, following the formulation of the dimensional indicators, the maximum value that a water company can get for each dimension is 1 . Therefore, for the social dimension, it can be seen that five water companies obtain remarkable results in comparison to others: Águas de Cascais, EPAL, SMAS de Sintra, Vimágua and SMSB de Viana do Castelo. According to its location, Águas de Cascais, EPAL, and SMAS de Sintra are located in MA Lisbon region, and Vimágua and SMSB de Viana do Castelo in North region. It can be seen that most of the water companies obtain poor results for this dimension and that just a few of them obtain values greater than 0.5 .

Likewise, an analysis within the environmental dimension reveals the good performance of Águas de Gondomar, Indaqua Matosinhos, Infraquinta, and Tavira Verde. Similarly, based on its location, Águas de Gondomar and Indaqua Matosinhos are located in the North region; and Infraquinta and Tavira Verde in the Algarve region. Aguas de Gondomar reaches the best position, since it provides the largest production of energy (IEN2). Note that each of these four better-positioned water companies produces between $14 \%$ and $20 \%$ of the energy that it uses. In general, most of the water companies obtain poor results in this dimension, too.

Additionally, in both of these dimensions, the values which indicate the certifications obtained for each water company plays an important role in the construction of the dimensional indicators, as determined in [12].

Finally, the results obtained for the economic dimension are ranged between 0.18 and 0.8 for all companies, highlighting Águas de Valongo and Indaqua Santo Tirso/Trofa, which are located in the North region. In particular, these water companies reach values greater than the average for all the initial indicators. In the data obtained, approximately the $56 \%$ of the water companies present an operating cost coverage ratio (IEC3) larger than the average.

In general, note that the best dimensional performance of the water companies is located in MA Lisbon, Algarve and North regions, despite the fact that more than a half of the companies (approximately 54\%) are located in the other two regions (Alentejo and Centre regions). 
In the same way, Table 3 shows the top 20 water companies for each dimension considered. It should be noted that there are four companies that appear among the top 20 in the three dimensions: Águas de Cascais, Águas de Valongo, Águas de Paredes, and Indaqua Matosinhos. Furthermore, 13 other companies stand out for two dimensions.

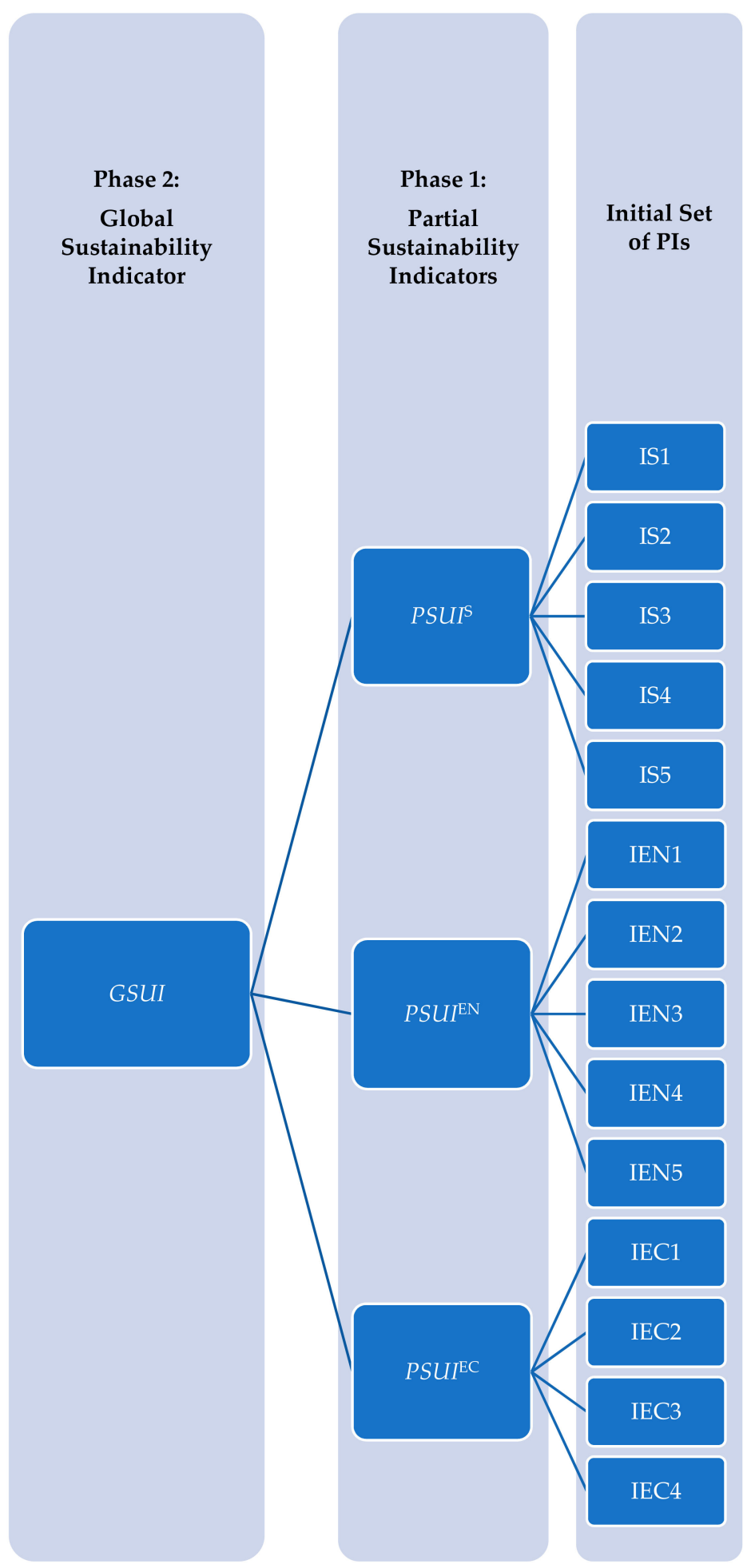

Figure 2. The two-phase approach applied to the case study. 


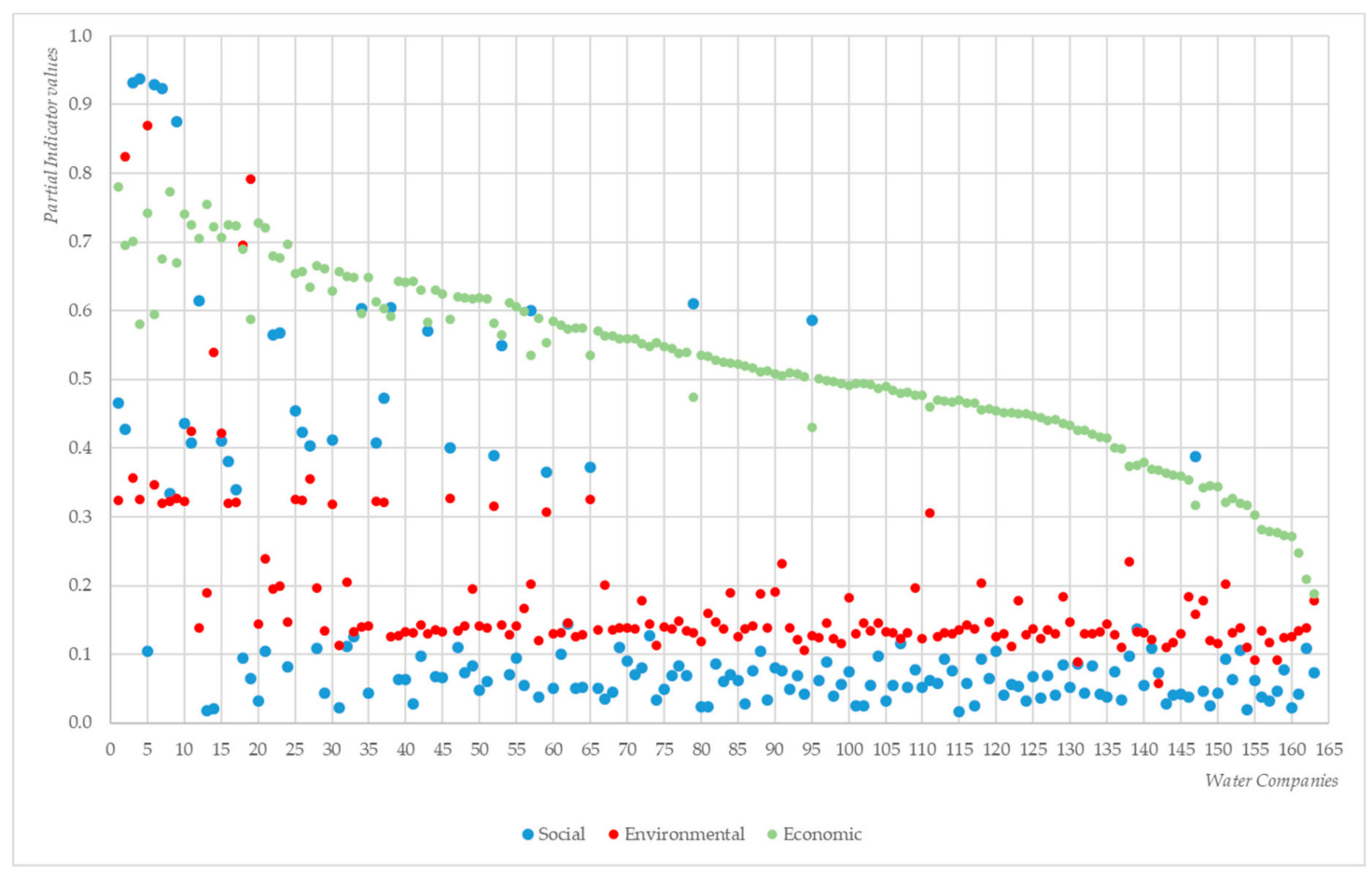

Figure 3. Dimensional results obtained for each of the 163 water companies.

Table 3. Top 20 water companies for each dimension.

\begin{tabular}{|c|c|c|c|c|c|}
\hline & PSUI $_{i}^{S}$ & & $P^{\prime} S I_{i}^{E N}$ & & $\operatorname{PSUI}_{i}^{E C}$ \\
\hline 4 VIMÁGUA & 0.937 & 5 Águas de Gondomar & 0.870 & 1 Águas de Valongo & 0.779 \\
\hline 3 Águas de Cascais & 0.931 & 2 Indaqua Matosinhos & 0.824 & 8 Indaqua Santo Tirso/Trofa & 0.772 \\
\hline 6 SMAS de Sintra & 0.928 & 19 INFRAQUINTA & 0.792 & 13 SM de Castelo Branco & 0.754 \\
\hline 7 EPAL & 0.923 & 18 Tavira Verde & 0.695 & 5 Águas de Gondomar & 0.742 \\
\hline 9 SMSB de Viana do Castelo & 0.876 & 14 Águas de Barcelos & 0.539 & 10 Águas de Paredes & 0.740 \\
\hline 12 Águas do Porto & 0.615 & 11 Indaqua Feira & 0.424 & 20 SMAS de Tomar & 0.727 \\
\hline 79 SMAS de Almada & 0.610 & 15 Águas de Alenquer & 0.422 & 11 Indaqua Feira & 0.725 \\
\hline 38 SMAS de Oeiras e Amadora & 0.604 & 3 Águas de Cascais & 0.356 & 16 INOVA & 0.724 \\
\hline 34 SMAS de Leiria & 0.603 & 27 FAGAR - Faro & 0.355 & 17 Indaqua Vila do Conde & 0.724 \\
\hline $163 \mathrm{CM}$ de Miranda do Corvo & 0.600 & 6 SMAS de Sintra & 0.346 & 14 Águas de Barcelos & 0.722 \\
\hline $95 \mathrm{SM}$ de Loures & 0.586 & 9 SMSB de Viana do Castelo & 0.327 & 21 Águas da Figueira & 0.721 \\
\hline 43 EMAS de Beja & 0.570 & 46 Cartágua & 0.326 & 15 Águas de Alenquer & 0.707 \\
\hline 23 Águas da Região de Aveiro & 0.568 & 25 Águas de Mafra & 0.326 & 12 Águas do Porto & 0.705 \\
\hline 22 Águas de Coimbra & 0.564 & 4 VIMÁGUA & 0.325 & 3 Águas de Cascais & 0.700 \\
\hline 53 CM de Santiago do Cacém & 0.549 & 65 Aquamaior & 0.325 & 24 Águas do Planalto & 0.697 \\
\hline 37 Aquaelvas & 0.472 & 26 AGERE & 0.324 & 2 Indaqua Matosinhos & 0.695 \\
\hline 1 Águas de Valongo & 0.466 & 1 Águas de Valongo & 0.323 & 18 Tavira Verde & 0.689 \\
\hline 25 Águas de Mafra & 0.454 & 10 Águas de Paredes & 0.323 & 22 Águas de Coimbra & 0.679 \\
\hline 10 Águas de Paredes & 0.435 & 36 Águas de Ourém & 0.323 & 23 Águas da Região de Aveiro & 0.677 \\
\hline 2 Indaqua Matosinhos & 0.428 & 8 Indaqua Santo Tirso/Trofa & 0.322 & 7 EPAL & 0.676 \\
\hline
\end{tabular}

Similarly, Table 4 shows the bottom 20 water companies for each dimension. In this case study, most of the companies (33) get bad results in just one of the three dimensions and only three water companies obtain poor results in the three dimensions: CM de Castelo de Paiva, CM de Arronches, and CM de Aljustrel. 
Table 4. Bottom 20 water companies for each dimension.

\begin{tabular}{|c|c|c|c|c|c|}
\hline & PSUI $_{i}^{S}$ & & $\operatorname{PSUII}_{i}^{E N}$ & & PSUI $_{i}^{E C}$ \\
\hline $137 \mathrm{CM}$ de Avis & 0.033 & 141 CM de Alijó & 0.121 & $144 \mathrm{CM}$ de Ferreira do Alentejo & 0.361 \\
\hline 124 CM de Mértola & 0.032 & $93 \mathrm{CM}$ de Armamar & 0.121 & $145 \mathrm{CM}$ de Marvão & 0.359 \\
\hline 157 CM de Castelo de Paiva & 0.032 & $149 \mathrm{CM}$ de Arronches & 0.120 & 146 CM de Lousã & 0.353 \\
\hline 105 CM de Almodôvar & 0.032 & 58 CM de Redondo & 0.120 & $149 \mathrm{CM}$ de Arronches & 0.345 \\
\hline 20 SMAS de Tomar & 0.032 & $80 \mathrm{CM}$ de Castro Verde & 0.119 & $150 \mathrm{CM}$ de Cabeceiras de Basto & 0.344 \\
\hline 41 INFRALOBO & 0.028 & $144 \mathrm{CM}$ de Ferreira do Alentejo & 0.118 & 148 CM de Alfândega da Fé & 0.343 \\
\hline 143 CM de Pinhel & 0.028 & 157 CM de Castelo de Paiva & 0.116 & $152 \mathrm{CM}$ de Murça & 0.326 \\
\hline $86 \mathrm{CM}$ de Odemira & 0.028 & $150 \mathrm{CM}$ de Cabeceiras de Basto & 0.116 & 151 CM de Sátão & 0.321 \\
\hline 149 CM de Arronches & 0.025 & 99 CM de São Brás de Alportel & 0.115 & 153 CM de Penalva do Castelo & 0.320 \\
\hline $117 \mathrm{CM}$ de Caminha & 0.025 & 31 CM de Póvoa de Varzim & 0.113 & $154 \mathrm{CM}$ de Aljustrel & 0.317 \\
\hline 102 CM de Évora & 0.025 & $74 \mathrm{CM}$ de Oliveira do Hospital & 0.112 & 147 CM de Santa Marta de Penaguião & 0.317 \\
\hline 101 CM de Figueiró dos Vinhos & 0.025 & $122 \mathrm{CM}$ de Estremoz & 0.112 & 155 CM de São João da Pesqueira & 0.303 \\
\hline $80 \mathrm{CM}$ de Castro Verde & 0.024 & 143 CM de Pinhel & 0.110 & 156 CM de Castanheira de Pera & 0.281 \\
\hline 81 SMAS de Guarda & 0.024 & 137 CM de Avis & 0.110 & 157 CM de Castelo de Paiva & 0.279 \\
\hline $160 \mathrm{CM}$ de Ourique & 0.023 & $154 \mathrm{CM}$ de Aljustrel & 0.110 & $158 \mathrm{CM}$ de Moimenta da Beira & 0.277 \\
\hline 31 CM de Póvoa de Varzim & 0.022 & 94 CM de Vila Nova de Famalicão & 0.105 & $159 \mathrm{CM}$ de Sabrosa & 0.274 \\
\hline 14 Águas de Barcelos & 0.020 & 155 CM de São João da Pesqueira & 0.092 & $160 \mathrm{CM}$ de Ourique & 0.271 \\
\hline 154 CM de Aljustrel & 0.020 & 158 CM de Moimenta da Beira & 0.091 & $161 \mathrm{CM}$ de Tabuaço & 0.247 \\
\hline $13 \mathrm{SM}$ de Castelo Branco & 0.018 & 131 CM de Proença-a-Nova & 0.088 & $162 \mathrm{CM}$ de Penedono & 0.209 \\
\hline 115 CM de Grândola & 0.016 & 142 INFRATROIA & 0.057 & 163 CM de Miranda do Douro & 0.187 \\
\hline
\end{tabular}

In managerial terms, within the top-20 rankings, those companies that follow the municipal concessionaire management model obtain good results in the environmental (13) and economic dimensions (11). Additionally, in the social dimension, the ranking is leaded by a mixture of water companies following different management models: municipal or State-owned companies (VIMÁGUA and EPAL), municipal concessionaire (Águas de Cascais), or direct management (SMAS de Sintra and SMSB de Viana do Castelo).

The results obtained in this section are of great interest for water regulators. They enable the operators to learn from the best positioned water companies in each dimension and establish operative strategies in the correct direction with the aim of reducing the weaknesses in the mid-term. In general, social and environmental issues are still insufficiently integrated into management processes and there is room to improve these dimensions. Regulators should promote certification programs to encourage water companies to make necessary improvements in order to obtain these certifications.

\subsubsection{Phase 2: $G S U I_{a}$ Calculation}

Once the dimensional indicators $\left(P S U I_{i}^{d}\right)$ are obtained for each water company, the optimization problem (Equation (7)) is applied in order to obtain the Global Sustainability Indicator proposed $\left(G S U I_{a}\right)$. These solutions will provide the weights for social (S), environmental (EN), and economic (EC) dimension, maximizing the global score for each water company. In this way, this problem provides the weights for social, environmental, and economic dimension, maximizing the global score for each water company. The lower and upper bounds of the constraints are set to 0.001 and $+\infty$, respectively. This ensures that each dimension represents, at least, the $0.1 \%$ of the global score.

Figure 4 shows the values obtained for $G_{S U I}$. It can be observed that there are five water companies (Águas de Cascais, Águas de Gondomar, Águas de Valongo, Indaqua Matosinhos, and Vimágua) that reach a value equal to 1 for the global indicator. EPAL, Indaqua Santo Tirso/Trofa and SMAS de Sintra are, also, very close to achieving a score of 1 . It should be noted that $42.95 \%$ of the set of water companies obtain a global value greater than 0.70 ; in particular, $25.15 \%$ of water companies obtain a global value greater than 0.80 . Then, a large group of water companies obtains good results, as they reach a value close to 1 . Additionally, there are no companies obtaining a global value lower than 0.20 . 


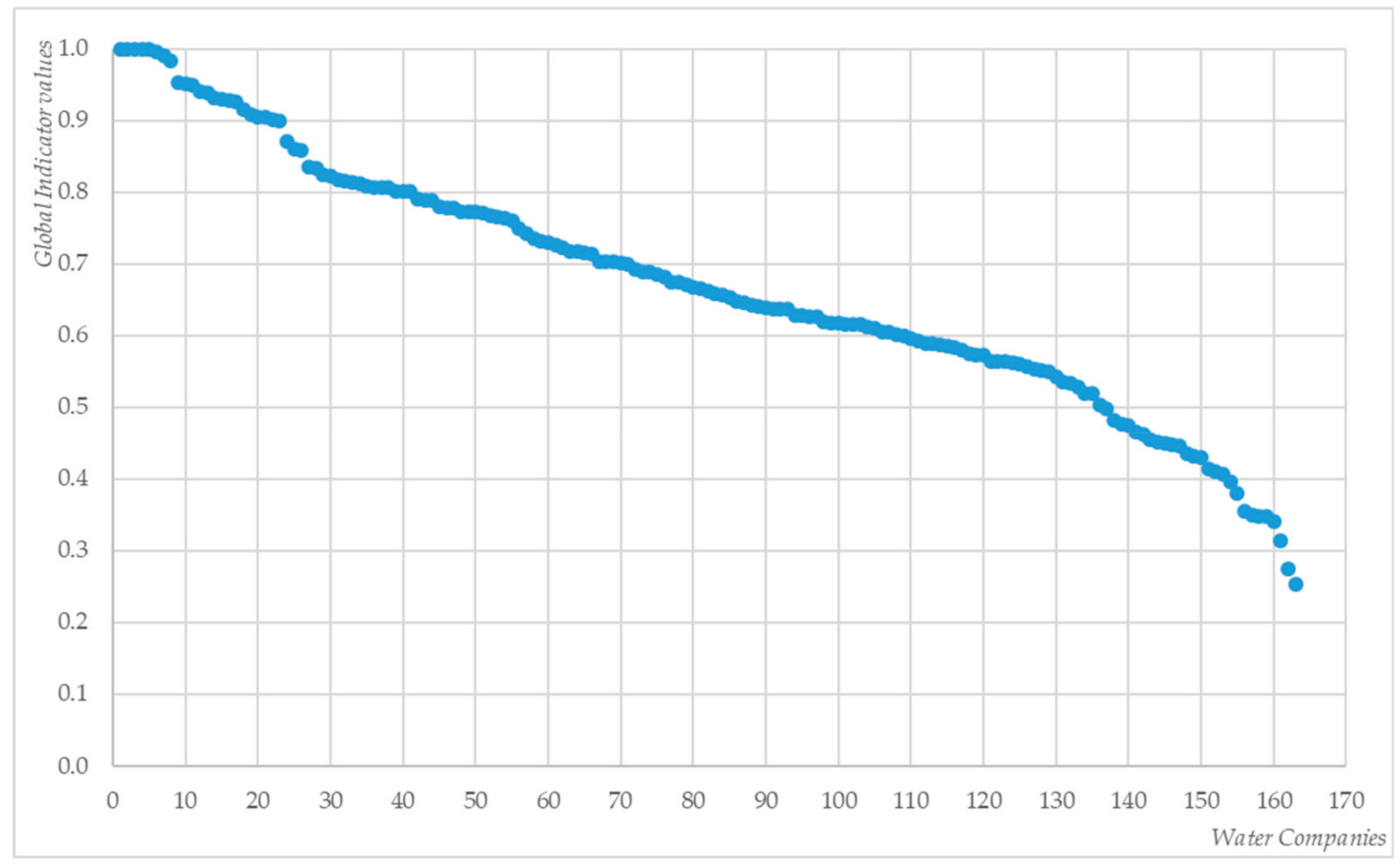

Figure 4. Global results obtained for each of the 163 water companies.

Table 5 lists all the water companies (163) according to the values obtained for the global indicator, $\mathrm{GSUI}_{a}$. On the one hand, regarding the best results, four companies that belong to the top-20 for every dimension also appear within the best global indicator values. Moreover, between the companies ranked better, based on GSUI, there are 11 water companies whose PSUI value leads them to the top-20 in two different dimensions. On the other hand, there are three companies that were part of the bottom ranking for all the dimensions and, also, for the global indicator value. In particular, between the 20 worst positioned water companies, based on the global indicator GSUI, there are four water companies that also appeared among the worst results for two dimensions. The other 13 water companies included in this bottom 20 ranking obtained poor results in the economic dimension.

An analysis about the correlation between all the rankings is shown in Table 6 using a Kendall tau test. Correlations are significant at $1 \%$ level and values obtained show a high correlation between the economic dimension ranking and the global ranking (0.925). The rest of the correlations are similar and positives, and they are ranged between 0.26 and 0.40 .

The proportional contribution differences can be explained by the particular profile characterizing each company. A global analysis reveals some influence of the location of the water companies in these lists. On the one hand, note that 12 of the top- 20 water companies are located in the North region, three water companies are located in MA Lisbon, three water companies are located in the Centre region, and two water companies are located in the Algarve region. No one of the top-20 water companies is located in Alentejo region. Additionally, the geographical distribution of these water companies with the best performance on GPSUI might be grouped into two main locations along the Portuguese coast: those companies that are placed close to Oporto (for example: Águas de Valongo, Indaqua Matosinhos, Águas de Gondomar, Indaqua Santo Tirso/Trofa, Águas de Paredes, Indaqua Feira, Águas do Porto), and the ones close to the capital (Águas de Cascais, SMAS de Sintra, EPAL). On the other hand, within the bottom-20 water companies, none of them is located in the MA Lisbon or in Algarve region. Nevertheless, most of them are located in the North region (11), five water companies are located in the Alentejo region, and four water companies are located in the Centre region. 
Table 5. Results for 163 water companies for global indicator.

\begin{tabular}{|c|c|c|c|}
\hline Water Company & $G_{S U I}$ & Water Company & GSUI $_{a}$ \\
\hline 1 Águas de Valongo & 1.000 & 83 CM de Nisa & 0.657 \\
\hline 2 Indaqua Matosinhos & 1.000 & $84 \mathrm{CM}$ de Arganil & 0.657 \\
\hline 3 Águas de Cascais & 1.000 & $85 \mathrm{CM}$ de Porto de Mós & 0.652 \\
\hline 4 VIMÁGUA & 1.000 & $86 \mathrm{CM}$ de Odemira & 0.648 \\
\hline 5 Águas de Gondomar & 1.000 & 87 Águas de Carrazeda & 0.647 \\
\hline 6 SMAS de Sintra & 0.995 & $88 \mathrm{CM}$ de Vale de Cambra & 0.643 \\
\hline 7 EPAL & 0.989 & $89 \mathrm{CM}$ de Arraiolos & 0.640 \\
\hline 8 Indaqua Santo Tirso/Trofa & 0.983 & $90 \mathrm{CM}$ de Espinho & 0.638 \\
\hline 9 SMSB de Viana do Castelo & 0.953 & 91 SMAS de Vila Franca de Xira & 0.636 \\
\hline 10 Águas de Paredes & 0.951 & 92 CM de Vila Viçosa & 0.636 \\
\hline 11 Indaqua Feira & 0.949 & $93 \mathrm{CM}$ de Armamar & 0.636 \\
\hline 12 Águas do Porto & 0.940 & 94 CM de Vila Nova de Famalicão & 0.629 \\
\hline 13 SM de Castelo Branco & 0.939 & 95 SM de Loures & 0.627 \\
\hline 14 Águas de Barcelos & 0.931 & 96 CM de Ponte de Sor & 0.627 \\
\hline 15 Águas de Alenquer & 0.930 & $97 \mathrm{CM}$ de Ponte da Barca & 0.626 \\
\hline 16 INOVA & 0.928 & $98 \mathrm{CM}$ de Seia & 0.620 \\
\hline 17 Indaqua Vila do Conde & 0.926 & 99 CM de São Brás de Alportel & 0.617 \\
\hline 18 Tavira Verde & 0.915 & $100 \mathrm{CM}$ de Se1bra & 0.617 \\
\hline 19 INFRAQUINTA & 0.908 & 101 CM de Figueiró dos Vinhos & 0.616 \\
\hline 20 SMAS de Tomar & 0.905 & 102 CM de Évora & 0.615 \\
\hline 21 Águas da Figueira & 0.904 & $103 \mathrm{CM}$ de Alandroal & 0.615 \\
\hline 22 Águas de Coimbra & 0.901 & $104 \mathrm{CM}$ de Aljezur & 0.612 \\
\hline 23 Águas da Região de Aveiro & 0.899 & 105 CM de Almodôvar & 0.610 \\
\hline 24 Águas do Planalto & 0.871 & 106 CM de Monção & 0.605 \\
\hline 25 Águas de Mafra & 0.861 & 107 CM de Óbidos & 0.604 \\
\hline 26 AGERE & 0.858 & 108 CM de Vila Nova de Foz Coa & 0.601 \\
\hline 27 FAGAR-Faro & 0.836 & 109 CM de Arcos de Valdevez & 0.599 \\
\hline $28 \mathrm{CM}$ de Albufeira & 0.834 & 110 AMBIOLHÃO & 0.596 \\
\hline 29 CM de Moita & 0.824 & 111 INFRAMOURA & 0.592 \\
\hline 30 Águas de S. João & 0.823 & 112 CM de Montemor-o-Velho & 0.588 \\
\hline 31 CM de Póvoa de Varzim & 0.816 & 113 CM de Cadaval & 0.588 \\
\hline 32 Luságua Alcanena-Gestão de Águas & 0.815 & $114 \mathrm{CM}$ de Terras de Bouro & 0.586 \\
\hline 33 EMAR de Portimão & 0.813 & 115 CM de Grândola & 0.585 \\
\hline 34 SMAS de Leiria & 0.811 & 116 CM de Alvaiázere & 0.583 \\
\hline 35 SMAS de Viseu & 0.809 & 117 CM de Caminha & 0.580 \\
\hline 36 Águas de Ourém & 0.807 & $118 \mathrm{CM}$ de Bombarral & 0.575 \\
\hline 37 Aquaelvas & 0.807 & $119 \mathrm{CM}$ de Mora & 0.573 \\
\hline 38 SMAS de Oeiras e Amadora & 0.806 & $120 \mathrm{CM}$ de Alcoutim & 0.572 \\
\hline 39 Águas do Sado & 0.801 & $121 \mathrm{CM}$ de Nelas & 0.565 \\
\hline 40 Águas do Ribatejo & 0.801 & $122 \mathrm{CM}$ de Estremoz & 0.564 \\
\hline 41 INFRALOBO & 0.801 & 123 CM de Mira & 0.564 \\
\hline 42 Águas da Azambuja & 0.790 & 124 CM de Mértola & 0.561 \\
\hline 43 EMAS de Beja & 0.789 & 125 SMAS de Peniche & 0.560 \\
\hline 44 SM de Alcobaça & 0.788 & 126 CM de Lamego & 0.556 \\
\hline 45 CM de Marinha Grande & 0.779 & $127 \mathrm{CM}$ de Castro Daire & 0.553 \\
\hline 46 Cartágua & 0.778 & 128 CM de Mourão & 0.551 \\
\hline $47 \mathrm{CM}$ de Sines & 0.777 & 129 CM de Penela & 0.549 \\
\hline 48 Águas do Lena & 0.773 & 130 CM de Ponte de Lima & 0.542 \\
\hline 49 CM de Vila Verde & 0.773 & 131 CM de Proença-a-Nova & 0.535 \\
\hline 50 CM de Seixal & 0.772 & $132 \mathrm{CM}$ de Soure & 0.533 \\
\hline 51 Penafiel Verde & 0.770 & 133 CM de Chaves & 0.529 \\
\hline 52 Águas de Santarém & 0.768 & 134 CM de Pedrógão Grande & 0.520 \\
\hline 53 CM de Santiago do Cacém & 0.765 & 135 CM de Ferreira do Zêzere & 0.519 \\
\hline 54 SM de Nazaré & 0.764 & 136 SMAS de Caldas da Rainha & 0.503 \\
\hline 55 Águas do Marco & 0.759 & $137 \mathrm{CM}$ de Avis & 0.498 \\
\hline 56 EMAR de Vila Real & 0.748 & $138 \mathrm{CM}$ de Vimioso & 0.482 \\
\hline 57 CM de Miranda do Corvo & 0.742 & 139 CM de Vila de Rei & 0.476 \\
\hline 58 CM de Redondo & 0.734 & 140 CM de Vila Nova de Poiares & 0.475 \\
\hline 59 Aquafundalia & 0.731 & 141 CM de Alijó & 0.466 \\
\hline 60 CM de Reguengos de Monsaraz & 0.730 & 142 INFRATROIA & 0.461 \\
\hline $61 \mathrm{CM}$ de Sousel & 0.726 & 143 CM de Pinhel & 0.455 \\
\hline $62 \mathrm{CM}$ de Mogadouro & 0.722 & $144 \mathrm{CM}$ de Ferreira do Alentejo & 0.451 \\
\hline 63 CM de Mealhada & 0.718 & 145 CM de Marvão & 0.450 \\
\hline $64 \mathrm{CM}$ de Almeida & 0.718 & 146 CM de Lousã & 0.447 \\
\hline
\end{tabular}


Table 5. Cont.

\begin{tabular}{|c|c|c|c|}
\hline Water Company & GSUI $_{a}$ & Water Company & $G S U I_{a}$ \\
\hline 65 Aquamaior & 0.715 & 147 CM de Santa Marta de Penaguião & 0.446 \\
\hline $66 \mathrm{CM}$ de Mangualde & 0.713 & 148 CM de Alfândega da Fé & 0.435 \\
\hline 67 SMAS de Montijo & 0.703 & 149 CM de Arronches & 0.432 \\
\hline $68 \mathrm{CM}$ de Barreiro & 0.703 & 150 CM de Cabeceiras de Basto & 0.431 \\
\hline $69 \mathrm{CM}$ de Pombal & 0.703 & 151 CM de Sátão & 0.415 \\
\hline 70 SMAS de Torres Vedras & 0.701 & 152 CM de Murça & 0.410 \\
\hline $71 \mathrm{CM}$ de Penacova & 0.699 & 153 CM de Penalva do Castelo & 0.406 \\
\hline 72 CM de Lagos & 0.692 & 154 CM de Aljustrel & 0.396 \\
\hline 73 CM de Góis & 0.689 & 155 CM de São João da Pesqueira & 0.381 \\
\hline $74 \mathrm{CM}$ de Oliveira do Hospital & 0.689 & 156 CM de Castanheira de Pera & 0.355 \\
\hline 75 CM de Montemor-o-Novo & 0.684 & 157 CM de Castelo de Paiva & 0.350 \\
\hline $76 \mathrm{CM}$ de Palmela & 0.682 & $158 \mathrm{CM}$ de Moimenta da Beira & 0.347 \\
\hline 77 CM de Ansião & 0.675 & 159 CM de Sabrosa & 0.347 \\
\hline 78 SM de Abrantes & 0.674 & $160 \mathrm{CM}$ de Ourique & 0.341 \\
\hline 79 SMAS de Almada & 0.671 & 161CM de Tabuaço & 0.314 \\
\hline 80 CM de Castro Verde & 0.666 & 162 CM de Penedono & 0.275 \\
\hline 81 SMAS de Guarda & 0.665 & 163 CM de Miranda do Douro & 0.253 \\
\hline 82 CM de Melgaço & 0.662 & & \\
\hline
\end{tabular}

Table 6. Kendall tau test.

\begin{tabular}{ccccc}
\hline $\begin{array}{c}\text { Rank Correlation } \\
\text { Coefficient }\end{array}$ & Global Ranking & Social Ranking & $\begin{array}{c}\text { Environmental } \\
\text { Ranking }\end{array}$ & $\begin{array}{c}\text { Economic } \\
\text { Ranking }\end{array}$ \\
\hline Global Ranking & 1.000 & & \\
Social Ranking & $0.324^{* *}$ & 1.000 & 1.000 & 1.000 \\
Environmental Ranking & $0.395^{* *}$ & $0.369^{* *}$ & $0.361^{* *}$ & \\
Economic Ranking & $0.925^{* *}$ & $0.261^{* *}$ &
\end{tabular}

In relation to the weights obtained by solving Equation (7), Table 7 summarizes the maximum and minimum values for the virtual outputs obtained, as well as their mean and standard deviation for each dimension. The economic dimension, in general, is the one with the largest virtual outputs in the global aggregation. As the reader may observe in Figure 3, almost all water companies obtain similar (good) values in this dimension. On the contrary, the social and the environmental dimensions lose importance in the global weighting. The results show how some companies obtained very good results in these dimensions but, at the same time, a larger proportion of the companies obtained relatively poor results.

Table 7. Statistical information for weights calculated.

\begin{tabular}{cccc}
\hline Descriptive Statistics & Social & Environmental & Economic \\
\hline Minimum & 0.001 & 0.001 & 0.003 \\
Maximum & 0.991 & 0.990 & 0.966 \\
Mean & 0.045 & 0.029 & 0.598 \\
Standard Deviation & 0.156 & 0.127 & 0.197 \\
\hline
\end{tabular}

Figure 5 shows the percentage contribution of each partial indicator to the value of the global composite indicator, for the top-20 water companies. Differences in percentage contribution can be explained by the particular profile characterizing each company. Despite the good performance of those 11 companies within the top-20 at each dimension, in the global score there is no company that displays a balanced contribution among the three dimensions. Then, if a balance between dimensions is searched, the best water companies of the global indicator are not a good reference for the others, in this context. In general, water companies should seek to improve their results in the dimension in which they obtained the worst results in the first phase, without neglecting the maintenance of good performance in those dimensions in which they obtained good results. Moreover, focusing on 
the companies that have a value equal to 1 in the global indicator, Águas de Cascais and VIMÁGUA exhibit a greater contribution of the social dimension, while Indaqua Matosinhos and Águas de Gondomar prioritize environmental dimension. However, Águas de Valongo stands out for the percentage contribution of the economic dimension, while a minor importance of the others. In the rest of companies, among those with a value of the global indicator close to 1 , it is worth mentioning that Indaqua Feira and Águas de Alenquer present a similar performance with an analogous contribution of each dimension, around $8 \%$ for the social dimension, $9 \%$ for the environmental dimension, and $83 \%$ for the economic one. In general, a trade-off between the economic dimension and the others can be observed jointly.

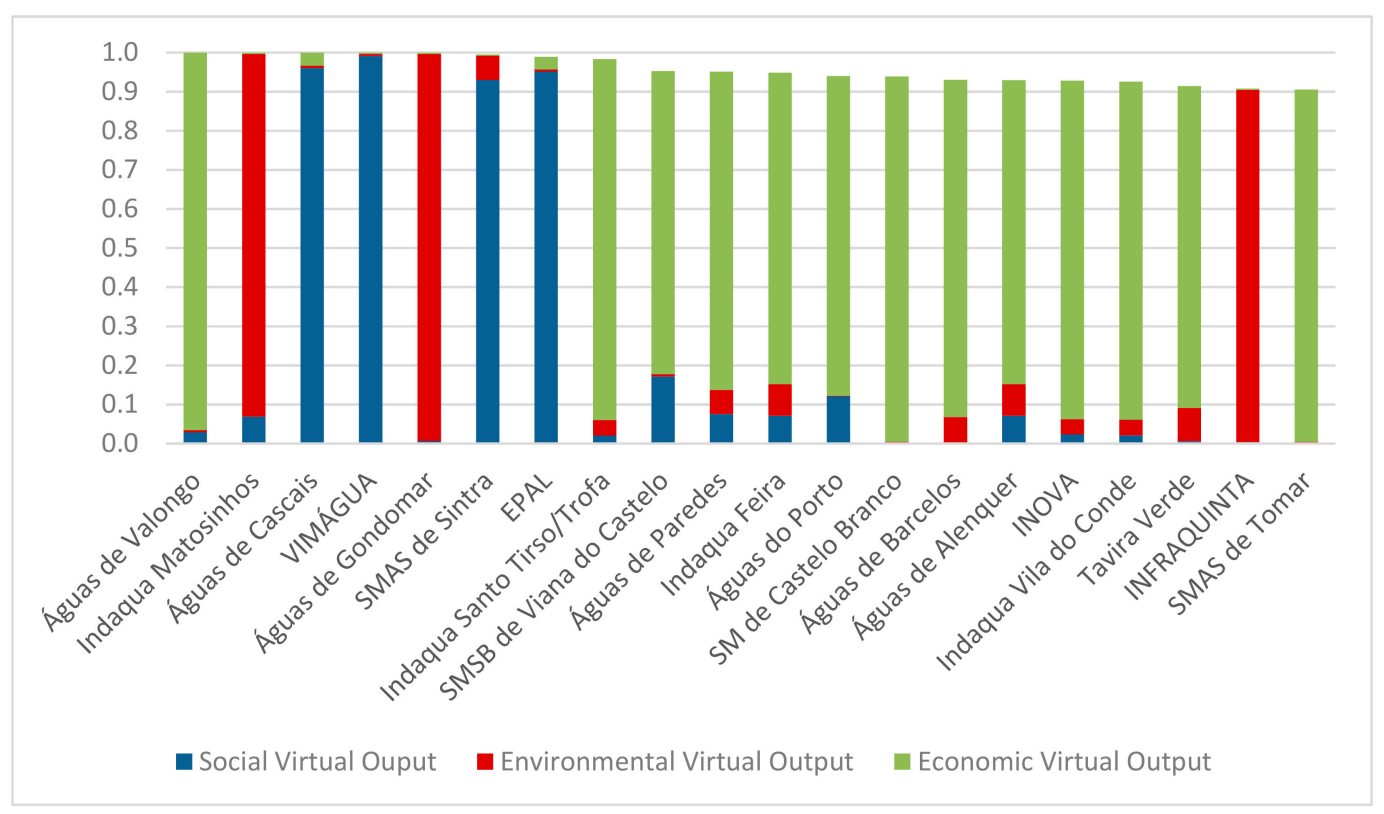

Figure 5. Contribution of each dimension partial indicator to the value of global composite indicator.

In managerial terms, within the top-20 ranking, ten companies that follows municipal concessionaire management model obtain good results the global indicator. The other ten companies present a fair distribution between the other two management models. Additionally, note that all water companies belonging to the bottom-20, use the municipal direct management model.

Then, the proposed approach allows evaluating the strengths and weaknesses of each water company in a particular dimension and, at the same time, provides information about the contribution of the dimensions to the sustainability overall score. These are the main advantages in comparison to the previous methodology. In fact, if the initial indicators are directly aggregated using the methodology based on goal programming, the results obtained regarding the best and the worst global performance of the water companies are similar to those obtained with the proposed two-phase approach. In particular, the top-13 using the previous methodology is formed by water companies that appear in our global top-20. Nevertheless, using the previous methodology, the advantages named above disappear because dimensional results are not obtained and, therefore, the contribution of them to the global indicator is missing.

Consequently, in light of the results obtained, it is necessary to perform some transformations towards sustainability with a balanced percentage contribution of each dimension. Implementing appropriate programs that highlight social and environmental aspects is required to address global sustainability in an adequate manner. Nevertheless, the proposed approach allows a better observation of the differences among the water companies, dimensional and globally. It eases identifying strengths and weaknesses of the companies, helping the decision-maker to set strategies to improve the mediumand long-term sustainability of such companies. 


\section{Conclusions}

Despite the multiple benefits brought by following an efficient performance, in water management only a few works provide alternatives. In this context, benchmarking plays an important role. Normally, to study the efficiency requires information collected by indicators. However, some difficulties arise when dealing with several indicators and their interpretation. In order to overcome these problems, CIs are introduced in this field, providing different strategies to aggregate the indicators into a unique score that summarizes the information.

In particular, this work provides an alternative methodology to evaluate the performance of a set of Portuguese water companies following two steps. First, in order to analyse the economic, social and environmental dimensions, we divide the initial set of indicators into these three dimensions and construct a partial sustainable index for each of them, inspired by GP. In general, water companies present the largest value for the economic partial sustainability indicator (PSUIEC), whereas the partial sustainable index for the social and environmental dimensions present poor scores, the former being slightly lower. In particular, ranking these results, we find that just a few water companies stand out among the top 20 best scores in the three dimensions, simultaneously. This fact could be translated into policies to improve social and environmental aspects of the water companies. The second step uses a variant of DEA to provide a global performance index that uses the information provided by the partial indicators for each company. As a result, a large percentage of water companies obtain a global score over 0.7 , whereas no companies show a value below 0.2 . However, an individual analysis of the contribution of each dimension to the global score shows no equilibrium.

Furthermore, in this analysis one may observe two profiles: on the one hand, many water companies present a good global score due to the value they achieve in the economic partial sustainability indicator, whereas, on the other hand, the good global results of the other companies are due to their performance in the social and environmental dimensions, jointly. The results obtained show that the water companies, in the Portuguese context, do not manage their activity in a balanced way from the social, environmental, and economic point of view. Consequently, there are no water companies, in this context, that can be considered a "good benchmark" for the rest, so that they achieved good results in the three dimensions in a balanced way. In this case, each water company should seek to improve their results in the dimension(s) with lower contribution in the sustainability, taking into account the scores in the first phase, without neglecting the maintenance of good performance in those dimensions in which good results are obtained. In this context, as a future line of research, it would be interesting to define an ideal company that reaches a good percentage contribution of each dimension on the sustainability, and then compare the sample of water companies with this one ideal.

Nevertheless, this work introduces an alternative to assess the sustainability of water companies in two phases. It permits assessing and/or comparing the dimensional sustainability in the first phase, and to provide a holistic performance perspective in the second phase, generating a ranking of the water companies. The proposed approach could be very useful for water regulators: (a) to verify the effectiveness of existing policies; (b) to support decision making in concrete dimensions; and (c) to monitor global trends. In other words, measuring sustainability, holistically and for dimension, will allow water regulators to make critical decisions and, if needed, implement corrective measures to improve it and do it in the correct direction.

Author Contributions: All authors contributed to the paper as follows. Conceptualization, F.P., L.D.-A. and T.G.; Methodology, F.P., L.D.-A. and T.G.; Software, F.P.; Validation, F.P., L.D.-A. and T.G.; Formal Analysis, F.P., L.D.-A. and T.G.; Investigation, L.D.-A.; Resources, F.P., L.D.-A. and T.G.; Data Curation T.G.; Writing-Original Draft Preparation, F.P., L.D.-A. and T.G.; Writing-Review and Editing, F.P., L.D.-A. and T.G.; Visualization, F.P., L.D.-A. and T.G.; Supervision, F.P., L.D.-A. and T.G.

Funding: This research was funded by Ministerio de Ciencia, Innovación y Universidades from Spain, grant number ECO2016-76567-C4-4-R; by the Consejería de Conocimiento, Investigación y Universidad from Junta de Andalucia [SEJ417] and by Universidad de Málaga, grant number PPIT.UMA.B1.2017.21.

Conflicts of Interest: The authors declare no conflict of interest. 


\section{Appendix A}

Table A1. Initial set of PIs.

\begin{tabular}{|c|c|c|}
\hline Dimension & Acronym & Performance Indicator \\
\hline \multirow{5}{*}{ Social } & IS1 & $\begin{array}{l}\text { Service coverage (\% of the households for which the water company } \\
\text { provides effective connected service) }\end{array}$ \\
\hline & IS2 & $\begin{array}{c}\text { Drinking water quality safety (\% of water supplied that meets the legal } \\
\text { quality requirements) }\end{array}$ \\
\hline & IS3 & $\begin{array}{l}\text { Reserve capacity for treated water (capacity to supply water of the } \\
\text { water company if new water resources are not available) }\end{array}$ \\
\hline & IS4 & $\begin{array}{l}\text { Certification of management systems for occupational risk and health } \\
\text { issues at work }\end{array}$ \\
\hline & IS5 & $\begin{array}{l}\text { Other certifications (corporate social responsibility, consumer protection } \\
\text { mechanisms,... ) }\end{array}$ \\
\hline \multirow{5}{*}{ Environmental } & IEN1 & Water losses in the network (volume of drinking water lost $/ \mathrm{km} /$ day) \\
\hline & IEN2 & $\begin{array}{c}\text { Internal power generation (\% of energy used own-generated by the } \\
\text { water company) }\end{array}$ \\
\hline & IEN3 & $\begin{array}{l}\text { Energy efficiency in pumping water (average consumption of energy } \\
\text { for water pumping) }\end{array}$ \\
\hline & IEN4 & $\begin{array}{l}\text { Certification of management systems (environmental responsibility, } \\
\text { environmental impact assessment mechanisms ... ) }\end{array}$ \\
\hline & IEN5 & Certification of management systems for water quality issues \\
\hline \multirow{4}{*}{ Economic } & IEC1 & Non-revenue water (\% of water that is supplied but not invoiced) \\
\hline & IEC2 & $\begin{array}{l}\text { Adequacy of staffing (number of full time equivalent employed / } 1000 \\
\text { water supply connections) }\end{array}$ \\
\hline & IEC3 & $\begin{array}{c}\text { Operating cost coverage ratio (total annual operational revenues / total } \\
\text { annual operational costs) }\end{array}$ \\
\hline & IEC4 & Index of knowledge about infrastructure and asset management \\
\hline
\end{tabular}

\section{References}

1. Carvalho, P.; Marques, R.C.; Berg, S. A meta-regression analysis of benchmarking studies on water utilities market structure. Util. Policy 2012, 21, 40-49. [CrossRef]

2. Molinos-Senante, M.; Gómez, T.; Garrido-Baserba, M.; Caballero, R.; Sala-Garrido, R. Assessing the sustainability of small wastewater treatment systems: A composite indicator approach. Sci. Total Environ. 2014, 54, 607-617. [CrossRef] [PubMed]

3. Giannetti, B.F.; Bonilla, S.H.; Silva, C.C.; Almeida, C.M.V.B. The reliability of experts' opinions in constructing a composite environmental index: The case of ESI 2005. J. Environ. Manag. 2009, 90, 2248-2459. [CrossRef] [PubMed]

4. Voces, R.; Díaz-Balteiro, L.; Romero, C. Characterization and explaination of the sustainability of the European wood manufacturing industries: A quantitative approach. Expert Syst. Appl. 2012, 39, 6618-6627. [CrossRef]

5. Blancas, F.J; Caballero, R.; González, M.; Lozano-Oyola, M.; Pérez, F. Goal programming synthetic indicators: An application for sustainable tourism in Andalusian coastal countries. Ecol. Econ. 2010, 69, 2158-2172. [CrossRef]

6. Pérez, V.; Guerrero, F.; González, M.; Pérez, F.; Caballero, R. Composite indicator for the assessment of sustainability: The case of Cuban nature-based tourism destinations. Ecol. Indic. 2013, 29, 316-324. [CrossRef]

7. Diaz-Balteiro, L.; Voces, R.; Romero, C. Making sustainability rankings using compromise programming. An application to European paper industry. Silv. Fenn. 2011, 45, 761-773. [CrossRef]

8. Sayed, H.; Hamed, R.; Hosny, S.H.; Abdelhamid, A.H. Avoiding Ranking Contradictions in Human Development Index Using Goal Programming. Soc. Indic. Res. 2018, 138, 405-442. [CrossRef]

9. Guijarro, F.; Poyatos, J.A. Designing a Sustainable Development Goal Index through a Goal Programming Model: The Case of EU-28 Countries. Sustainability 2018, 10, 3167. [CrossRef]

10. Valcárcel-Aguiar, B.; Murias, P. Evaluation and Management of Urban Liveability: A Goal Programming Based Composite Indicator. Soc. Indic. Res. 2019, 142, 689-712. [CrossRef]

11. Xavier, A.; Costa Freitas, M.B.; Fragoso, R.; Rosário, M.S. A regional composite indicator for analysing agricultural sustainability in Portugal: A goal programming approach. Ecol. Indic. 2018, 89, 84-100. [CrossRef] 
12. Molinos-Senante, M.; Marques, R.C.; Pérez, F.; Gómez, T.; Sala-Garrido, R.; Caballero, R. Assessing the Sustainability of water companies: A synthetic indicator approach. Ecol. Indic. 2016, 61, 577-587. [CrossRef]

13. Cherchye, L.; Moesen, W.; Rogge, N.; Van Puyenbroeck, T. Creating Composite Indicators with DEA Analysis: The Case of the Technology Achievement Index; Joint Research Centre, European Commission: Ispra, Italy, 2006.

14. Murias, P.; de Miguel, J.C.; Rodríguez, D. A composite indicator for university quality assessment: The case of Spanish higher education system. Soc. Indic. Res. 2008, 89, 129-146. [CrossRef]

15. Castellet, L.; Molinos-Senante, M. Efficiency assessment of wastewater treatment plants: A data envelopment analysis approach integrating technical, economic, and environmental issues. J. Environ. Manag. 2016, 167, 160-166. [CrossRef]

16. Hernández-Sancho, F.; Sala-Garrido, R. Technical efficiency and cost analysis in wastewater treatment processes: A DEA approach. Desalination 2009, 249, 230-234. [CrossRef]

17. Dong, X.; Zhang, X.; Zeng, S. Measuring and explaining eco-efficiencies of wastewater treatment plants in China: An uncertainty analysis perspective. Water Res. 2017, 112, 195-207. [CrossRef] [PubMed]

18. Holden, E.; Linnerud, K.; Banister, D. Sustainable development: Our Common Future revisited. Glob. Environ. Chang. 2014, 26, 130-139. [CrossRef]

19. Pinto, F.S.; Costa, A.S.; Figueira, J.R.; Marques, R.C. The quality of service: An overall performance assessment for water utilities. Omega 2017, 69, 115-125. [CrossRef]

20. WECD, Our Common Future; Oxford University Press: Oxford, UK, 1987.

21. LoStorto, C. Efficiency, conflicting goals and trade-offs: A nonparametric analysis of the water and wastewater service industry in Italy. Sustainability 2018, 10, 919. [CrossRef]

22. Arnold, M. The lack of strategic sustainability orientation in German water companies. Ecol. Econ. 2015, 117, 39-52. [CrossRef]

23. Moller, K.A.; Fryd, O.; De Neergaard, A.; Magid, G. Economic, environmental and socio-cultural sustainability of three constructed wetlands in Thailand. Environ. Urban. 2012, 24, 305-323. [CrossRef]

24. Marques, R.C.; da Cruz, N.F.; Pires, J.S. Measuring the sustainability of urban water services. Environ. Sci. Policy 2015, 54, 142-151. [CrossRef]

25. Aydin, N.Y.; Mays, L.; Schmitt, T. Sustainability assessment of urban water distribution systems. Water Res. Manag. 2014, 28, 4373-4384. [CrossRef]

26. Hamouda, M.A.; Nour El-Din, M.M.; Moursy, F.I. Vulnerability assessment of water resoiurces systems in the Eastern Nile basin. Water Res. Manag. 2009, 23, 2697-2725. [CrossRef]

27. Lundie, S.; Peters, G.; Ashbolt, N.; Lai, E.; Livingston, D. A sustainability framework for the Australian water industry. Water 2010, 33, 83-88.

28. Schulz, M.; Short, M.D.; Peters, G.M. A streamlined sustainability assessment tool for improved decision making in the urban water industry. Integr. Environ. Assess. Manag. 2012, 8, 183-193. [CrossRef] [PubMed]

29. Ahn, J.; Kang, D. Optimal planning of water supply system for long-term sustainability. J. Hydro Environ. Res. 2014, 8, 410-420. [CrossRef]

30. Duarte, A.A.L.S.; Rodrigues, G.M.C.; Ramos, R.A.R. A global service quality index to evaluate the performance and sustainability in water supply utilities. WSEAS Trans. Environ. Dev. 2009, 5, 759-769.

31. Bana-e-Costa, C.A.; Vansnick, J.C. MACBETH-An interactive path towards the construction of cardinal value functions. Int. Trans. Oper. Res. 1994, 1, 489-500. [CrossRef]

32. Almeida-Dias, J.; Figueira, J.R.; Roy, B. ELECTRE TRI-C: A multiple-criteria sorting method based on characteristic reference actions. Eur. J. Oper. Res. 2010, 240, 565-580. [CrossRef]

33. Blancas, F.J.; Caballero, R.; Lozano-Oyola, M.; Pérez, F. The assessment of sustainable tourism: Application to Spanish coastal destinations. Ecol. Indic. 2010, 10, 484-492. [CrossRef]

34. Environmental Protection Agency. Planning for Sustainability. A Handbook for Water and Wastewater Utilities; EPA: Seattle, DC, USA, 2012.

35. Diaz-Balteiro, L.; González-Pachón, J.; Romero, C. Measuring systems sustainability with multi-criteria methods: A critical review. Eur. J. Oper. Res. 2017, 258, 607-616. [CrossRef]

36. Cherchye, L.; Moesen, W.; Rogge, N.; van Puyenbroeck, T. An introduction to "benefit of the Doubt" Composite Indicators. Soc. Indic. Res. 2006, 82, 111-145. [CrossRef]

37. Zhou, P.; Ang, B.W.; Poh, K.L. A mathematical programming approach to constructing. Ecol. Econ. 2007, 62, 291-297. [CrossRef] 
38. Despotis, D.K. Measuring human development via data envelopment analysis: The case of Asia and the Pacific. Omega 2005, 33, 385-390. [CrossRef]

39. Marques, R.C.; Simões, P. Does the sunshine regulatory approach work? Governance and regulation model of the urban waste services in Portugal. Resour. Conserv. Recycl. 2008, 52, 1040-1049. [CrossRef]

40. Lozano-Oyola, M.; Blancas, F.J.; González, M.; Caballero, R. Sustainable tourism indicators as planning tools in cultural destinations. Ecol. Indic. 2012, 18, 659-675. [CrossRef]

41. Pérez, F.; Molinos-Senante, M.; Gómez, T.; Caballero, R.; Sala-Garrido, R. Dynamic goal programming synthetic indicator: An application for water companies sustainability assessment. Urb. Water J. 2018, 15, 592-600. [CrossRef]

(C) 2019 by the authors. Licensee MDPI, Basel, Switzerland. This article is an open access article distributed under the terms and conditions of the Creative Commons Attribution (CC BY) license (http://creativecommons.org/licenses/by/4.0/). 